\title{
A GAZDASÁGI KOMMUNIKÁCIÓ TÁRGYKÖREI
}

\author{
Nagy Ágnes \\ nagy.tanar@windowslive.com
}

D O I : 10.20520/JEL - K E P.2017.2.47

\begin{abstract}
Absztrakt
A tanulmány célja a gazdasági kommunikáció sokféle értelmezésének a számba vétele és rendszerezése. Ez a rendszerezés azért tünik ésszerü és szükséges feladatnak, mert a gazdasági kommunikációnak nincs egységes és általánosan elfogadott ételmezése: különböző szerzők és iskolák különbözőképpen írják le és elemzik. Több szerző és megközelítés áttekintésének eredményeként a terminus használatának négy típusát lehet megkülönböztetni: a gazdasági élet egészével kapcsolatos kommunikáció, a vállalatokon belüli és közötti kommunikáció, a pénzügyekkel kapcsolatos kommunikáció és a gazdasági tartalmú médiakommunikáció. Az egymást gyakran átfedő használatoknak a jellemzésében a gazdasági kommunikációt olyan komplex fogalomnak tekintem, amely makro- és mikroszinten különféle tárgykörökböl, interakciókból és következményekböl épül fel.
\end{abstract}

\section{Kulcsszavak}

globális, vállalati, pénzügyi, média gazdasági kommunikáció

\section{THE SUBJECTS OF ECONOMIC COMMUNICATION} Ágnes Nagy

\begin{abstract}
The aim of this study is to take into account and systematize the various interpretations of economic communication. This systematization seems to be a reasonable and necessary task, because there isn't a uniform, generally accepted concept of economic communication: different authors and schools describe and analyze it in different ways. As a result of a survey of several authors and approaches, the following typical uses of the term can be distinguished: communication related to the entire economic life, communication within and between companies, financial communication, and media communication of economic content. In the characterization of these - sometimes overlaping - uses, economic communication is considered as a complex concept composed of several macro- and microeconomic topics, interactions and consequences.
\end{abstract}

\section{Keywords}

global, corporate, financial, media economic communication 


\title{
A GAZDASÁGI KOMMUNIKÁCIÓ T Á R G Y K Ö R E I
}

\author{
Nagy Ágnes
}

\section{Bevezetés}

A gazdasági kommunikáció (economic communication) mint kutatási terület alapjának a gazdasági nyelvészet elnevezéssel elterjedt kutatások tekinthetők. Ezek a kutatások egyfelöl a gazdasági nyelvezet megismerésén keresztül a gazdaságtörténet leírásához járultak hozzá, másfelől a közgazdaságtudomány nyelvészeti vizsgálódásai szempontjából váltak relevánsakká. Elsőként említhető a nyelvet a vállalati szükségletek kielégítésére alkalmas eszköznek tekintő a közgazdasági megközelítés, amely nélkül maga a vállalati tevékenység is elképzelhetetlen. A másik szempont az ún. nyelvi jellegü gazdasági vállalkozások (pl. könyv, sajtó stb.) vizsgálatát helyezte fókuszba, amelyek által a nyelv értékteremtő (és értékesíthető) tényezővé vált (Borgulya 2010). A nyelvészeti orientációjú vizsgálatok a gazdasági szaknyelv vonatkozásában számos kutatással bővültek (lásd Ablonczyné 2006, 2007, 2010, Nagy 2015b, Proietti 2010). Ezek a kutatások, többek között a gazdasági kommunikációt mint szaknyelvet elemezve, elösegítették például a szakszókincs jellegzetességeinek feltárását.

Amennyiben a gazdasági kommunikáció mint terminus értelmezését kívánjuk megismerni, az tapasztalható, hogy a szerzők különféle módon határozzák meg a fogalmát, más és más gondolatokat társítanak hozzá. Önmagában a terminushoz kapcsolódó gondolattársítások rendszerezése is egyfajta kihívást jelent, amennyiben elöfeltételezzük, hogy a gazdasági kommunikáció egy komplex, rendszerezésre szoruló kutatási terület. A rendszerezés első lépéseként a gazdasági kommunikáció értelmezési lehetőségeinek feltárását tűztem ki célul. Az értelmezési lehetőségek sokaságát látva arra kényszerültem, hogy csupán néhány fontosabb megközelítést vegyek figyelembe annak érdekében, hogy valamelyest átlátható rendszerezés jöhessen létre.

Így lényegében háromféle elgondolást tartalmaz a végső rendszerezés: (i) a közgazdaságtani makroszintü, (ii) mikroszintü és (iii) a szervezetek hatásköre szerinti elhatárolást, amelyet Niklas Luhmann rendszerelméleti vonatkozásaival egészítettem ki. Luhmann rendszerelmélete két aspektusból releváns: egyfelől a társadalom „,minden kölcsönösen hozzáférhető kommunikációk átfogó rendszere" (Bognár - Karácsony 2014: 306), másfelől a gazdaság mint szociális részrendszer beágyazódik a társadalmi rendszer egészébe. A tárgykörök között nem lehet éles határt húzni sem általánosan, sem Luhmann rendszerelmélete vonatkozásában. A gazdaság - mint a társadalom maga is - valamely környezetben létezik, amely nélkül elhatárolása is értelmetlen lenne, azaz a környezet és a gazdaság egyes területei egyaránt hatást gyakorolnak egymásra. Erre példa a politikai részrendszer protekcionista döntésekkel kifejtett befolyása a gazdasági kommunikáció tárgyköreire: a globális kommunikáció színterén érvényesülö protekcionista magatartás azt „kommunikálja” a többi szint felé, hogy zárják be a világ többi része felé az ajtókat. 


\section{A gazdasági kommunikáció a nyelvészeti kutatások aspektusából}

A gazdasági kommunikáció vizsgálatával foglalkozó kutatások első megjelenési formáinak az 1800-as évek végén a kereskedelem, a gazdaságtan nyelvére vonatkozó nyelvtörténeti kutatások tekinthetők. Rendszeres kutatási területté a múlt századtól vált azoknak a nyelvészeti kutatásoknak az eredményeként, amelyek gazdasági nyelvészet elnevezéssel terjedtek el, és gazdaságtörténeti, valamint közgazdaságtudományi megközelítéseket öleltek fel. A gazdasági nyelvészeti kutatás egyik ága Prágához köthető, ahol a vállalati és elméleti gazdasági szövegek stilisztikai elemzésével foglalkoztak mélyrehatóan. Ezzel egyidejüleg bontakozott ki az ún. strukturális- és funkcionális gazdasági nyelvészet, amely a gazdasági szaknyelvet mint funkcionális egészet gazdasági célokat szolgáló kommunikációs eszköznek tekintette (Borgulya 2010). A 21. századi gazdasági nyelvészeti kutatások között számos olyan tanulmány látott napvilágot, amely a gazdaság szaknyelvi jellegzetességeit ismerteti különböző megközelítésekben (lásd Ablonczyné 2006, 2007, 2010, Nagy 2015b, Proietti 2010, stb.). Ablonczyné (2006) három tényezőt emel ki a szaknyelv vizsgálata során: a témát, a helyszínt és a kommunikátort. A nyelvi kontextust alapvetően meghatározza, hogy ki a kommunikátor és milyen szférában alkalmazza az adott szaknyelvet, ennek megfelelően szociolingvisztikai aspektusból megkülönböztethető a tudományos szaknyelvi, a szakmai szaknyelvi és a köznyelvi szaknyelvi szint (Ablonczyné 2006). A gazdasági szaknyelvi szókincsről általában elmondható, hogy az egyes gazdasági szakterületeken belül változó. Proietti (2010) például különválasztja a gazdasági és pénzügyi nyelvezetet, mint szektor nyelvezeteket, valamint a gazdasági szaknyelven belül további negyven féle területet különít el (például a gazdaságpolitikát, a politikai gazdaságtant, a gazdasági jogot, a pénzügyi és vállalati nyelvezetet, ezen belül a marketinget és a menedzsmentet stb.). A gazdasági szaknyelv tehát önmagában komplex szaknyelvi kategória (Ablonczyné 2006), és ezen komplexitás érvényes a gazdasági kommunikáció értelmezésének vonatkozásában is.

\section{A gazdasági kommunikáció terminus értelmezési problémái}

A gazdasági kommunikáció terminus jelentése körül némi zürzavar tapasztalható, amelyre korábban már Borgulya is utalt: „A napi szóhasználatban a szervezeti, a gazdasági, az üzleti, a vállalati és a vezetői kommunikáció elnevezések nagyon gyakran keverednek, sok használó nem érez jelentésbeli különbségeket." (Borgulya 2010: 4)

A probléma egyik okának tekinthető, hogy a múlt századtól a gazdasági kommunikáció elnevezéshez sorolták a gazdasági nyelvészeti kutatások egy részét, ide értve az üzleti, a szervezeti és a vállalati kommunikációt is, ezáltal különböző fogalmakat összekeverve (Borgulya 2010). Jóllehet a differenciálódás folyamata már a múlt század utolsó évtizedeiben megkezdödött, napjainkban is jellemzö, hogy az elöbb említett fogalmakat szinonimaként használják a szakirodalmakban. A terminus értelmezésének eltérései Borgulya (2010) és Kővágó (2011) müveiben is megmutatkoznak.

Borgulya a gazdasági kommunikáció körét a gazdasági jelzőből kiindulva határozza meg: „A gazdasági jelző a magyar nyelvben a gazdasági élet egészét jellemző folyamatokhoz kötődő kommunikáció jelölésére alkalmas. A gazdasági rendszerek, gazdaságpolitikai, makrogazdasági összefüggések leírása (például egy nemzetgazdaság-fejlesztési koncepció, vagy az Európai Unió gazdasági célkitűzéseinek közzététele, megvitatása) a gazdasági kommunikáció körébe tartozik.” (Borgulya 2010: 4)

Kővágó (2011) „A gazdasági kommunikáció struktúrája” alfejezetben a gazdasági kommunikáció tárgyköreit funkcionális alapon különíti el: „Mellőzve az értéksorrendet és a teljesség igényét, a gazdasági kommunikáció tárgykörébe tartozik a 
- termelési (üzemszervezési, technológiai stb.),

- logisztikai,

- munkaügyi,

- személyügyi (humánszolgálati),

- pénzügyi (befektetői, részvényei, pénzügyi szervezeti stb.), valamint - a továbbiakban terjedelmi okokból csak ezekkel foglalkozunk - a megtermelt javak elöállításában és értékesítésében kimagasló szerepet játszó,

- üzleti és

• marketingkommunikáció.” (Kővágó 2011: 249)

A fenti két idézet alapján megállapítható, hogy míg Borgulya (2010) a gazdasági kommunikációt a gazdasági jelzőből kiindulva elsősorban a gazdaság egészére vonatkozó folyamatokkal azonosítja, addig Kővágó (2011) lényegében különböző vállalati részterületeket sorol a tárgykörébe. A következőkben a teljesség igénye nélkül néhány példát idézek a nemzetközi szakirodalomból a gazdasági kommunikáció definícióira, amelyek a pénz cseréjével, az üzleti információk áramlásával, a gazdasági médiatartalommal vannak összefüggésben.

\section{A gazdasági kommunikáció definícióinak nemzetközi példái}

Az alábbiakban ismertetendő definíciók különféle elméleti megközelítéseket tartalmaznak, amelyek nem pusztán a fogalmi szintü meghatározás alapján különböznek, hanem a vizsgálat kiindulópontja tekintetében is.

A Beckert és Zafirovski (2006) szerkesztésében készült A gazdaságszociológia nemzetközi enciklopédiájában (International encyclopedia of economic sociology) Richard Münch a gazdasági kommunikáció fogalmát Luhmann rendszerelméletével összefüggésben határozza meg: „A gazdasági kommunikáció a pénz cseréje vagy egy egyszerü kifizetés, és a gazdaság az, ahol pénzt fizetnek és fogadnak el.” (Beckert - Zafirovski 2006: 418) „1 „A gazdasági kommunikáció a likvid eszközök folyamatos átruházását jelenti az egyik személytől a másiknak.” (Beckert - Zafirovski 2006: 667) ${ }^{2}$

Edoardo Brioschi (2006) - Coda (1989) és Di Stefano (1990) meghatározására hivatkozva - a gazdasági kommunikáció fogalmát az üzleti környezethez kapcsolódóan definiálja: „A gazdasági kommunikáció - ahogy összefoglalóan Coda (1989: 7) megállapította - értelmezhetö úgy, mint az információk továbbítása az üzleti tevékenység bevételi, pénzügyi és vagyoni helyzetének alakulásáról a felső vezetéstől a társadalmi párbeszédben megjelenő összes (vagy néhány) résztvevő felé, megkülönböztetés nélkül. [...] Azt lehet mondani - pontosabban meghatározva -, hogy a kommunikáció nem szorítkozik az üzleti tevékenység bevételi, pénzügyi és vagyoni helyzetének alakulására, hanem megpróbálja megmagyarázni, vagy legalábbis olyan tényezőket biztosítani, amelyek tisztázzák a tartalmát. [...] A gazdasági kommunikáció, amely amennyire lehetséges megpróbál magyarázattal szolgálni az üzleti tevékenység gazdasági tendenciájáról, tartalmában mindkettőt felöleli: a múltban megvalósított stratégiát és a jövőben alkalmazottat egyaránt (Di Stefano 1990: 151).” (Brioschi 2006: 167) ${ }^{3}$

1 „Economic communication is monetary exchange or simply a payment, and the economy 'is' where money is paid and received." (Beckert - Zafirovski 2006: 418)

2 „Economic communication is the continuous handing over of liquidity from one person to another person.” (Beckert - Zafirovski 2006: 667)

3 „Economic communication - as synthetically stated (Coda 1989: 7) - can be intended as the conveyance of information about the evolution of income, finance and patrimony conditions of the busi- 
Rosanne Scholl a gazdasági kommunikációt elsősorban a médiatartalomhoz kapcsolódóan határozza meg: „A gazdasági kommunikáció a gazdasági médiatartalmak, vagy az általános médiatartalom gazdasági hatásainak szociológiai tudományterülete. A gazdasági kommunikáció magában foglalhatja az interperszonális beszélgetés gazdasági jellegű tartalmát is, de ez a tanulmány a tömegmédia gazdasági jellegü tartalmaira szorítkozik." (Scholl 2008: 6) ${ }^{4}$

A fenti meghatározásokról a következők mondhatók el. A Luhmann rendszerelméletére támaszkdó meghatározás mögött természetesen olyan összetett összefüggések húzódnak meg, amelyeket a társadalom leírását szolgáló, a filozófia és a szociológia határmezsgyéjén elhelyezhető tudományos megközelítés foglal magába (lásd Bognár - Karácsony 2014, Brunczel 2010, Luhmann 2011). Így az első definíció - Richard Münché a Beckert és Zafirovski (2006) enciklopédiában - a rendszerelméletből a gazdasági részrendszerre vonatkozó információkat tartalmaz. Az üzleti kommunikációhoz kötődő meghatározás (Brioschi 2006) kiindulási pontja az üzleti környezetben jellemző információáramlással van kapcsolatban, ennek megfelelően kizárólag azon szempontok relevánsak a szerző számára, amelyek az üzleti élettel hozhatók összefüggésbe. Végül Scholl (2008) a gazdasági híreket vagy a hírek gazdasági hatásait tekinti gazdasági kommunikációnak. A szerző egyidejűleg elismeri, hogy tudományos környezetben gyakorta elkerülik a gazdasági kommunikáció terminus használatát, amely tágabb értelmezést ölel fel, mint a média kommunikáció, azonban vizsgálatát a gazdasági jellegü tömegkommunikációra korlátozza.

Összefoglalóan megállapítható, hogy a gazdasági kommunikáció interpretációja a szakemberek között nem egységes. Az eltérő értelmezésekből adódó dilemma feloldásának egyik módja az lehet, hogy a gazdasági kommunikációt olyan gyüjtőfogalomnak tekintjük, amely tárgyköröket foglal magába.

\section{A gazdasági kommunikáció tárgykörei}

A gazdasági kommunikáció tárgyköreinek meghatározása több nézőpontból is lehetséges. Az előzőekben írtaknak megfelelően hangsúlyozandó, hogy nincs egyetlen olyan megoldás, amely átfedéstöl mentes elkülönítést biztosít. Első megközelítésben - a legtágabb értelmezésben - közgazdaságtani megfontolásokat alapul véve a korábbiakban ismertetett megközelítések feloszthatók makro- és mikrószintüekre: a kizárólag általános érvényü, globális témaköröket felölelö meghatározások (Münch 2006, Borgulya 2010) a makroszinthez, míg a vállalati (Kővágó 2011), üzleti (Brioschi 2006) témakörök és a gazdasági tömegkommunikáció (Scholl 2008) a mikroszinthez tartozhatnak.

Egy másik aspektusból, a Münch féle (Beckert - Zafirovski 2006) leíráshoz kapcsolódóan figyelembe vehetők Luhmann rendszerelméletéből a kommunikációk alapján kialakult szociális részrendszerek (politika, gazdaság, tudomány stb.), amelyek ,a modern társadalomban, alapvetően a különböző társadalmi funkciók teljesítésére specializálódott részrendszerek.” (Bognár - Karácsony 2014: 308). A korábbiakban ismertetett definíciók a szociális

ness from the top management to all the social interlocutors without distinction (or to some of them) [...] Said communication - as specified - is not restricted to the description of the evolution of the income, finance and patrimony situation of the business, but is tries to explain it or, at least, to provide useful elements to clarify it. [...] Economic communication that tries to explain, as it should, the economic trend of the business, includes in its content both the strategy carried out in the past and the one which is to be adopted in the future." (Di Stefano 1990: 151, In: Brioschi 2006: 167)

4 „Economic communication is a sociological study of economic media content or economic effects of general media content. Economic communication may also include economic content of interpersonal talk, but this essay restricts itself to mass mediate economic content." (Scholl 2008: 6) 
rendszerek közül a gazdasági részrendszerrel és a tömegmédia részrendszerével hozhatók öszszefüggésbe, valamint azokkal a szervezetekkel (vállalatok), amelyek a szociális rendszerek közötti strukturális kapcsolódás megtestesítői.

A tárgykörök rendszerezésének további kiindulópontja lehet a gazdasági kommunikációt közvetítő szervezetek társadalmi-gazdasági szerepének figyelembe vétele. Ebben az értelemben azok a szervezetek, amelyek a globális, integrációs vagy nemzetgazdasági szinten jelennek meg, a globális gazdasági kommunikáció tárgyköreihez sorolhatók (tág értelemben a makroszintü kommunikáció színterén). Ezekre a szervezetekre az a jellemző, hogy a kommunikációjuk és döntéseik egy-egy nemzetre vagy nemzetek integrációjára vonatkoznak, és a gazdasági szférára jelentős hatást gyakorolhatnak akár globálisan is (pl. a kamatlábak szabályozása esetében). A nemzeti és nemzetközi pénzügyi intézmények tipikusan ilyen jellegü szervezeteknek tekinthetők a gazdaságban, de ide sorolható például a Világkereskedelmi Szervezet (WTO) is. A gazdasági kommunikáció tárgyköreinek elkülönítése szempontjából ez tekinthető úgy, mint a globális (átfogó) gazdasági kommunikáció tárgyköre.

A vállalatok a korábbi tágabb értelmü meghatározás szerint a mikroszinthez tartoznak, amelynél elsőként Kővágó (2011) - fenntebb már idézett - funkcionális struktúráját érdemes figyelembe venni. Az abban elsorolt tárgyköröket (termelési, logisztikai, munkaügyi, befektetői, üzleti és marketingkommunikáció) célszerü a vállalati kommunikáció részterületeinek tekinteni, és az így kialakított struktúrában a vállalati gazdasági kommunikáció elnevezést használni.

Az eddigiek alapján a gazdasági kommunikáció tárgykörei közgazdaságtani, a szervezetek társadalmi-gazdasági szerepe, valamint Luhmann elmélete szempontjából az alábbiak szerint csoportosíthatók:

- makroszinten:

- globális gazdasági kommunikáció: a gazdasági élet egészét jellemző folyamatokhoz kötődő kommunikáció (Borgulya 2010), amely Luhmann nyomán a gazdasági részrendszerrel hozható összefüggésbe;

- mikroszinten:

- vállalati gazdasági kommunikáció (Kővágó 2011), Luhmann nyomán például azok a szervezetek, amelyek a részrendszerek közötti strukturális kapcsolódást biztosítják;

- gazdasági jellegü tömegkommunikáció és gazdasági médiatartalom (Scholl 2008), amely Luhmann nyomán a tömegmédia részrendszerével hozható öszszefüggésbe.

Ezek az elhatárolások alkalmatlanok az egyes tárgykörök témaköreinek egyértelmü elválasztására, például a gazdasági élet egészét érintő információk minden tárgykör kommunikációja során megjelennek, így a pénzügyi információk természetesen a nemzetközi, a vállalati és a tömegkommunikáció tárgyköreinek is egyaránt a témái. Konkrét példa: a kamatlábak alakulása lehet egy nemzeti vagy egy nemzetközi szintü szervezet kommunikációjának is a tárgya, amely a vállalati-pénzügyi kommunikációban két módon jelenhet meg: a pénzügyi intézmények esetében a kamatlábak alakulásával és közzétételével kapcsolatos információkkal, a kereskedelmi és szolgáltató vállalatok esetében pedig a pénzügyi információkkal összefüggésben. Végül, de nem utolsó sorban a gazdasági jellegű tömegkommunikáció szervezetei különböző médiumokon keresztül közvetítik a kamatlábak alakulásával kapcsolatos döntéseket. Mindez nem pusztán a kommunikáció tárgyát határozza meg, hanem egyéb következményeket is von maga után, például az árak vagy a hitelek és megtakarítások alakulásának tekintetében, ami minden szint kommunikációjának része. 
A következőkben az egyes tárgykörökön belül jellemző lehetséges szervezeteket és témákat mutatok be, elsősorban a korábban ismertetett definíciók alapján. A vállalati gazdasági kommunikáció tárgykörein belül a pénzügyi kommunikációt kiemelem a gazdaságban betöltött sajátos szerepe és a jogszabályi követelmények miatt.

\section{Globális gazdasági kommunikáció (a gazdasági élet egészét jellemző folyamatokhoz. kötödö kommunikáció)}

A gazdasági élet egészét jellemző folyamatokhoz kötődő kommunikáció makroszinten értelmezhetö, amelyre példa lehet ,a gazdasági rendszerek, gazdaságpolitikai, makrogazdasági összefüggések leírása (például egy nemzetgazdaság-fejlesztési koncepció, vagy az Európai Unió gazdasági célkitűzéseinek közzététele, megvitatása)." (Borgulya 2010: 4) Tágabb értelemben ez a tárgykör tehát felöleli a társadalmi-gazdasági (közgazdaságtani) elméleteket, a nemzetközi gazdasági szervezetek (OECD, Eurostat, CETA), gazdasági integrációk tevékenységével, az államok közötti kereskedelmi együttműködésekkel (protekcionizmus versus liberalizmus), a gazdasági-társadalmi jólét mutatószámaival (Nagy 2016a, 2016b) összefüggő információkat.

A globális gazdasági kommunikáció tárgyköre Robert Münch (Beckert és Zafirovski 2006) Luhmann rendszerelméletével összefüggő definícióját is magába foglalja, amely alapján a gazdasági kommunikáció a pénz cseréjét, illetve a kifizetéseket jelenti.

\section{Luhmann gazdasági részrendszerre vonatkozó elméletének néhány eleme}

Luhmann rendszerelméletében - amelynek terjedelmi okokból csak néhány aspektusára térhetek ki - a gazdaság a szociális rendszerek egyik funkcionális részrendszere, amelynek szimbolikusan általánosított kommunikációs médiuma a pénz (Brunczel 2010). A szociális rendszerekre jellemző bináris kód határozza meg müködését, a birtokolni/nem birtokolni kód és kiegészülése, azaz másodkódolása a fizetni/nem fizetni kód. A „gazdaság létkérdése”, hogy tudunk-e fizetni vagy sem, más szavakkal: „Gazdaságon azoknak a müveleteknek az összeségét kell értenünk, amelyek pénzkifizetések révén mennek végbe" (Luhmann 2010: 65). A pénz, a gazdasági részrendszer szimbolikusan általánosított kommunikációs médiuma biztosítja a másodrendủ megfigyelést, azt, hogy „mások miként figyelik meg a rendszert, vagyis milyen áron hajlandóak vásárolni és eladni." (Brunczel 2010: 93)

Luhmann elgondolása alapján tehát a gazdasági részrendszer önszabályozása az árak révén valósul meg, és kifizetésekből áll. A pénz körforgása által a fizetőképesség és a fizetöképtelenség 'kódjai' váltakoznak; ahhoz hogy a rendszer müködöképes maradjon folyamatosan biztosítani kell a fizetőképesség lehetőségét, azaz a pénzszerzés forrását, amely elsősorban munkahelyi jövedelmekből származik. A modern gazdaság rendszerében a fizetőképesség fenntartása a cél, tőkére van szükség, amely áthidalja a kifizetés és a fizetőképesség visszaállítása között eltelt időt. A rendszer műveleti autopoiészisze így a fizetőképesség és fizetésképtelenség körforgásában realizálódik az idő nyomása alatt, ehhez a rendszernek önszabályozása révén biztosítania kell a rentabilitás fenntartását és mindazon gazdasági feltételeket, amelyek a közfeladatok ellátásához és a munkahelyteremtéshez kapcsolódnak. Amenynyiben a körforgás nem teremti meg automatikusan a fizetöképességet a rendszerben, a hitelmechanizmus biztosíthatja a fizetőképesség létrehozását, amit a központi bankok szabályozhatnak. Azáltal, hogy a központi bankok a pénzemisszió kizárólagos jogával vannak felruházva, egyúttal lehetőségük van a fizetőképtelenséget fizetöképességgé alakítani. A pénzpiac így meghatározza a rendszer és a piacok müködését egyaránt.

A modern gazdasági részrendszer, amelyet a pénz rendkívül gyors áramlása határoz meg, a pénzmechanizmus által különül el a többi részrendszertöl; a külső beavatkozás mikéntje Luhmann szerint kétséges. A gazdasági részrendszerre és különösen a pénzpiacokra 
- például az árfolyamok alakulására - olyan gyors müködés jellemző, hogy az pusztán az események megfigyelésére ad lehetőséget, azonban nem határozható meg strukturálisan, nem foglalható 'keretrendszerbe', müködése nem irányítható más részrendszerek által (Luhmann 2010). A funkcionális részrendszerek egyik jellemzője, hogy nem töltenek be irányító szerepet egy másik részrendszerben, azaz a gazdasági részrendszer esetében sem a politikai, sem a jogi részrendszer nem képes irányítani, müveleti kapcsolat a szervezetek révén valósul meg a rendszerek között. Ezzel azonban csak részleges befolyást tudnak gyakorolni a gazdaság egy részére, azonban nem az egészére. A gazdaság, mint önszabályozó rendszer úgy határozható meg, hogy funkciója a hiány csökkentése, médiuma a pénz, kódjai a fizetés/nem fizetés (Brunczel 2010).

Felvetődhet a kérdés, hogy a központi bankok mint pénzügyi szervezetek a globális gazdasági kommunikáció részei, vagy pedig a pénzügyi szférához tartozó szervezetek kommunikációjának színteréhez tartoznak. Minthogy tevékenységük és kommunikációjuk a teljes gazdasági életet befolyásolja, ami makroszinten értelmezendő, a nemzetközi és állami pénzügyi szervezeteket a globális gazdasági kommunikáció tárgyköréhez sorolhatjuk.

A gazdaság egészére vonatkozó témakörök természetesen további témákra tagolhatók, így például Luhmann rendszerelméletének a gazdasági részrendszerre vonatkozó elmélete elmélyíthető és összevethető más elméletekkel, és további lehetőség a nemzetközi gazdasági szervezetek, kereskedelmi megállapodások (pl. Canada EU Trade Agreement - CETA) vagy az országok közötti kereskedelmi kapcsolatok elemzése (pl. USA-Kína, lásd Bown 2016), amelyek világosan kereskedelempolitikai kérdéskörök. A globális gazdasági kommunikáció színterén a kereskedelempolitikai döntések meghatározó mértékben befolyásolják az összes színtér kommunikációját és tevékenységét. A kereskedelempolitika Luhmann elméletében a politikai részrendszer beavatkozását jelenti a gazdasági részrendszerbe. A politikai részrendszer beavatkozása a gazdasági részrendszerbe protekcionista eszmékkel azt jelenti, hogy szükülnek a választási lehetőségek minden színtéren. Ez globálisan egyfajta elzárkózást jelent a világ többi részétől, ami retorziót válthat ki a többi ország részéről, így végső soron gátolhatja a gazdaság fejlödését. Ellenkező esetben a liberalizmus, pontosabban a kereskedelmi megállapodások (lásd Bown 2011, 2017) által szabályozott globális kereskedelmi rendszer hatásaival kapcsolatos vizsgálatok alapján olyan pozitív eredmények tapasztalhatók, amelyek jelentősen felülírják a káros hatásokat (lásd IMF, World Bank, WTO 2017).

\section{Vállalati gazdasági kommunikáció}

A Kővágó (2011) által a gazdasági kommunikáció funkcionális strukturálása során funkcionálisan elkülönített területek - termelési, logisztikai, munkaügyi, befektetői, üzleti és marketing - két módon értelmezhetők: egyfelöl úgy, hogy azok a vállalaton belüli részlegeket jelentik, tehát a vállalat jellegétől függően jelen vannak a szervezetben. Lehetséges például, hogy egy vállalat több elkülönült részleggel rendelkezik (pl. termelői részleg, logisztikai részleg, munkaügyi részleg stb.). Tapasztalataim alapján ez leginkább a nagyvállalatoknál, a multivagy transznacionális cégeknél jellemző.

Másfelől értelmezhetők a funkciók úgy is, mint elkülönült funkciókra specializálódott szervezetek. Például termeléssel foglalkozó vállalat, logisztikára, munka- és személyügyekre (pl. fejvadász), pénzügyekre (pl. bank), üzletre (pl. kiskereskedelmi bolt) vagy marketing tevékenységre specializálódott vállalalatok. Természetesen ezen szervezeteken belül is létezhetnek különböző vállalati funkciók, azonban itt a fötevékenység alapján különíthetők el a vállalatok. Általánosan megfogalmazva a vállalati gazdasági kommunikáció a következő módon határozható meg: „Vállalati kommunikáción a szervezet tagjainak mindennemü kommunikatív cselekvését értjük, amellyel a gazdálkodó egységben hozzájárulnak a javak előállítását célzó feladatok meghatározáshoz és teljesítéséhez (Zerfaß 1996: 287). Ily módon a vállalati 
kommunikáció körébe tartoznak a vállalat tagjai intern, valamint extern csoportjai között folyó, a vállalati célokat szolgáló kommunikációs tevékenységek.” (Borgulya 2010: 5).

Brioschi (2006) korábban ismertetett definíciója a gazdasági kommunikációra vonatkozóan lényegében a bevételi, pénzügyi és vagyoni helyzet alakulásához kapcsolódó üzleti információk áramlását hangsúlyozza a vállalat intern és extern csoportjai között, amely a vállalati kommunikáció fontos részterületét jelenti és leginkább a vállalati gazdasági kommunikáción tárgykörén belül az üzleti kommunikációhoz tartozónak tekinthető. Az üzleti kommunikáció (business communication) az üzleti tevékenységhez kapcsolódó mindazon kommunikációs tevékenységeket magába foglalja, amelyek az értékesítési tevékenységhez kapcsolódnak, így például az üzleti tárgyalást, a termékbemutatót, az üzleti levelezést, telefonbeszélgetést (Kővágó 2011, Borgulya 2010).

A vállalati gazdasági kommunikáció területén belül kiemelendő a pénzügyi gazdasági kommunikáció tárgyköre. A pénzügyi információk a gazdasági kommunikáció minden tárgykörének részei, azaz nem létezik olyan szervezet, amelynek kommunikációja ne foglalna magában pénzügyi vonatkozásokat. A pénzügyi szféra tehát közvetítő szerepet tölt be, szervezeti szempontból viszont sajátos jellegzetességekkel bír a vállalati gazdasági kommunikáció tárgykörén belül. Ennek megjelenési formája a specifikus tevékenységi kör mellett az a jogszabályi környezetet, amely kihat a szervezeti forma választási lehetőségeire és a szolgáltatások nyújtásának módjára egyaránt.

\section{A pénzügyi gazdasági kommunikáció}

A pénzügyi gazdasági kommunikáció Kővágó (2011) felsorolása alapján a befektetői, részvényesi, pénzügyi szervezeti stb. területeket foglalja magában. A pénzügyi gazdasági kommunikáció témái a pénzintézeti és tőzsdei, azaz a pénz- és tőkepiaci információkat ölelik fel. A pénzügyi kommunikáció tárgyköre és a globális gazdasági kommunikáció tárgyköre között átfedés állapítható meg az előzőekben említett nemzetközi és állami pénzügyi szervezetek miatt, amelyeket potenciális hatásukra tekintettel a globális gazdasági kommunikáció tárgyköréhez sorolhatunk. A pénzügyi kommunikáció tárgyköréhez elsőként azokat a pénzügyi intézményeket vélem célszerünek figyelembe venni, amelyeket a 2013. évi CCXXXVII. törvény a hitelintézetekröl és a pénzügyi vállalkozásokról és a közvetítőkröl tartalmaz:

„7. § (1) Pénzügyi intézmény a hitelintézet és a pénzügyi vállalkozás.”

„8. § (1) Hitelintézet az a pénzügyi intézmény, amely a 3. §-ban meghatározott pénzügyi szolgáltatások közül legalább betétet gyüjt, vagy más visszafizetendő pénzeszközt fogad el a nyilvánosságtól - ide nem értve a jogszabályban meghatározott nyilvános kötvénykibocsátást, valamint hitelt és pénzkölcsönt nyújt."

„9. § (1) Pénzügyi vállalkozás:

a) az a pénzügyi intézmény, amely - a 3. § (1) bekezdés d) és e) pontjában, valamint a 8 . $\S(2)$ bekezdésében meghatározott tevékenység kivételével -, egy vagy több pénzügyi szolgáltatást, vagy fizetési rendszer müködtetését végzi, és

b) a pénzügyi holding társaság."

„10. § (1) Közvetítő az, aki az e törvényben foglaltaknak megfelelően

a) a pénzügyi szolgáltatás közvetítését

aa) kiemelt közvetítői tevékenységként egy pénzügyi intézmény - ideértve a pénzügyi intézmény csoportját is - vagy több pénzügyi intézmény egymással nem versengő pénzügyi szolgáltatása vonatkozásában (a továbbiakban: kiemelt közvetítö), vagy 
ab) ügynöki tevékenységként egy pénzügyi intézmény - ideértve a pénzügyi intézmény csoportját is - vagy több pénzügyi intézmény egymással nem versengő pénzügyi szolgáltatása vonatkozásában (a továbbiakban: függő ügynök), vagy

ac) pénzforgalmi közvetítői tevékenységként végez (a továbbiakban együtt: függő közvetítő), vagy

b) a pénzügyi szolgáltatás közvetítését

ba) kiemelt közvetítői tevékenységként több pénzügyi intézmény egymással versengő pénzügyi szolgáltatása vonatkozásában (a továbbiakban: többes kiemelt közvetítö), vagy

bc) alkuszi tevékenységként (a továbbiakban: alkusz) végez (a továbbiakban együtt: független közvetítö)." (Netjogtár 2017a)

Továbbá a befektetési vállalkozások és az árutőzsdei szolgáltatók is a pénzügyi gazdasági kommunikációt közvetítő szereplők közé sorolhatók, amelyeknek tevékenységét a 2007. évi CXXXVIII. törvény a befektetési vállalkozásokról és az árutőzsdei szolgáltatókról, valamint az általuk végezhető tevékenységek szabályairól határozza meg (Netjogtár 2017b).

Az elöbbi pénzügyi szervezetek kommunikációja több szempontból sajátosnak tekinthető például szaknyelvi szempontból. A pénzügyi szaknyelv egy része az általános szaknyelvi szókincs része (pl. folyószámla, bankkártya, hitel, kamat stb.), vagy annak kellene lennie például a hitelezés folyamatában jellemző szakszavak esetében (pl. a teljes hiteldíj mutató elvileg az általános szaknyelvi szókincs részét kellene, hogy képezze). Továbbá szakspecifikus terminusokat tartalmaznak például a pénzügyi szervezetek beszámolói, vagy a banki folyamatmenedzsment gyakorlata a törvényi elöírásokhoz igazodva (Nagy 2009). A pénz- és tőkepiaci információk specifikusak többek között a befektetések vonatkozásában is, értelmezésük egyedi felkészültségeket igényel.

A pénzügyi piacok kommunikációját nyilvánvalóan befolyásolják a globális szintű gazdasági döntések, ami például a kamatlábak alakulásában mutatkozik meg (a hitelkamatok és a betéti kamatok jelenlegi viszonylag alacsony mértékében). A kamatpolitika végig gyürüzik a teljes gazdaságon, meghatározza a vállalati és egyéni hitelezések és megtakarítások mértékét, a gazdaságba áramló pénz mennyiségét, valamint a vállalati és egyéni választási lehetőségeket az áru és pénzügyi piacokon egyaránt. Konkrétan az eladósodás mértéke, a hitelek visszafizetésének lehetósége vagy éppen lehetetlensége egyfajta frusztrációt okozhat a gazdaság szereplői számára és pusztán anyagi megfontolások által vezérelt választásokra kényszeríti a fogyasztókat, ami valószínűsíthetően nem a jó minőségű termékeknek kedvez. Más szavakkal, a hitelpénznek semmi értelme sincs, ha kétes a visszafizetésének a forrása; ez a gazdasági szereplőket arra kényszerítheti, hogy restriktív intézkedésekkel fogják vissza gazdasági aktivitásukat, ami végső soron a gazdasági növekedést akadályozza. Ráadásul a politikai részrendszert nacionalista magatartási formák kialakítására ösztökéli, ahogyan napjainkban ezt számos gyakorlati példa alátámasztja.

A vállalati és ezen belül a pénzügyi szervezetek azok a gazdasági szervezetek, amelyek Luhmann rendszerelméletében a funkcionális részrendszerek (gazdasági, politikai, jogi stb.) közötti strukturális kapcsolódást biztosítják. A közöttük megvalósuló kommunikáció által hatással vannak egymásra, ami a rendszer és a környezet kölcsönös függőségét jelenti. Az egymás közötti függőség vagy irritáció a változtatás elöidézője lehet az egyes részrendszerek kommunikációjának vonatkozásában. A társadalmi részrendszerek kapcsolódása, tehát a kommunikáció a rendszerek között a szervezetek közremüködésével lehetséges, amelyek jellemzően rendszerspecifikusak, így beszélhetünk gazdasági, politikai vagy tudományos szervezetekről. Strukturális kapcsolódásnak tekinthetők az adók és a járulékok a politikai és a gazda- 
sági rendszerek között, a szerződések és a tulajdon pedig a jogi és gazdasági rendszerek kapcsolatára példa. Az egyes részrendszerekre sajátos mủveleti kód és kommunikációk jellemzők, ami nem zárja ki, hogy ugyanazon kommunikációs müvelet több részrendszerhez is tartozhasson. Például egy jogi szankció következményeként fizetendő összeg a fizetés teljesítése esetén gazdasági tranzakció is. A rendszerelméletben jellemző bináris kód a szervezetek esetében a tagság/kívülállók kódok alapján valósul meg, a tagok belépése feltételekhez kötött a szervezeten belül, ami döntésen alapul. A döntés, mint a szervezet müveleti kódja, speciális kommunikációtípusként a zárt rendszer müködését biztosítja. A gazdasági szervezetek a globális gazdasági kommunikáció területén is jelen vannak, döntési hatáskörük azonban jelentősebb a vállalati szintnél (pl. központi bankok). Mind a globális gazdasági kommunikáció, mind a vállalati gazdasági kommunikáció szervezetei által 'kibocsátott' információ a tömegmédia, mint szociális részrendszer szimbolikusan általánosított médiuma (Bognár Karácsony 2014, Brunczel 2010), amelynek egy része a gazdasági jellegü tömegkommunikáció tárgyköréhez tartozik.

\section{Gazdasági jellegü tömegkommunikáció (gazdasági médiatartalom)}

A gazdasági jellegü tömegkommunikáció szervezetei kevésbé definiálhatók oly módon, mint a globális vagy vállalati gazdasági kommunikáció tárgykörei. Hagyományos értelemben azok a médiaszervezetek, amelyek alapvetően valamilyen társasági formában müködnek, mint értékteremtő vállalatok vannak jelen a gazdaságban. A tömegmédia azonban ennél tágabban értelmezhető a modern társadalomban az internet révén biztosított információközlés határtalan lehetősége miatt, amely lényegében szervezettől függetlenül bárki számára nyitott platform az információk közlésére. Nyilvánvaló, hogy az információ valóságtartalma tekintetében szükség van a gazdasági médiatartalmak szelekciójára, így szük értelemben azokat a médiaszervezeteket (pl. sajtó, televízió) érdemes figyelembe venni, amelyek hitelesnek mondhatók, illetve hosszútávon minőségi információkat közölnek. A gazdasági tömegmédia által közölt információk egy része származtatott információ, azaz hivatalos szervezetek (a globális és a vállalati gazdasági kommunikáció szervezetei) által közölt információkat tartalmaz, ami az egyes elkülönített tárgykörök közötti szoros összekapcsolódásra utal.

A gazdasági tömegkommunikáció a médium vagy a téma alapján számos területet ölelhet fel. A tárgykör összetett jellegére utal Rosanne Scholl, aki a gazdasági kommunikációt a szociológia tudományterületének részeként határozta meg, a gazdasági médiatartalmak vagy az általános médiatartalmak gazdasági hatásainak elemzésével összefüggésben (Scholl 2008). A gazdasági médiainformációk hatása a tudományos kutatások tárgyának is részei, így például azok a kutatások, amelyek a gazdasági sajtóban megjelenő makrogazdasági információk hatását vizsgálták az értékpapírpiacokra (Beber - Brandt 2006, Boyd et al. 2005, Hanousek et al. 2009, Kim et al. 2004, Shaikh - Padhi 2013) vagy az árfolyamok alakulására (Frömmel et al. 2011, Pearce - Solakoglu 2007). A tömegkommunikáció hatását elemző kutatások elősegíthetik többek között a pénzpiaci mozgások elörejelzését. A gazdasági hírek vizsgálati részének tekinthető a sajtó negatív vagy pozitív polaritásának vizsgálata, amely alapul szolgálhat a további elemzésekhez (Nagy 2015c). Nem utolsó sorban a gazdasági sajtó elemzés során a makrogazdasági mutatók gyakorisági vizsgálata a társadalomban preferált indikátorok megismerését segíti elő, ami egyidejüleg lehetőséget nyújt arra, hogy rámutasson, valójában menynyire fontosak azok a tényezők, amelyek például az ökológiai vagy a gender problémákkal foglalkoznak (Nagy 2016a, 2016b).

Luhmann rendszerelméletében a tömegmédiumok társadalmi beágyazódása a témák révén valósul meg, amelyeknél, amennyiben informatívnak minősíthetők, tovább terjedésük biztosítja fennmaradásukat (Luhmann 2011). A tömegmédiának mint szociális rendszernek szimbolikusan általánosított médiuma az információ, kódjait az informatív/nem informatív 
elemek alkotják (Brunczel 2010). A tömegmédia részrendszerében a médiatartalom sajátossága az informativitásának az időbeli korlátozottsága: ami egyszer megjelenik a médiában, az elveszti újdonság jellegét és nem informatív többé. Ahogy a friss pénz a gazdaságban, úgy a friss információ a tömegmédia részrendszerében folyamatos szükségletként van jelen. A tömegmédia funkciója egyfelől az információigény fenntartása és az információéhes közönség folyamatos táplálása. Másfelöl szerepe van a társadalmi valóságalkotás folyamatában, ami idöröl időre változó témakörök mentén valósul meg (Luhmann 2011). A valóságkonstrukció alakulása jelentős részben a tömegmédia felelőssége, amely képes befolyásolni a társadalmi-gazdasági értékrendet, a gondolkodásmódot az egyes témák tekintetében. A gazdasági rendszerek, a kereskedelempolitika, a pénzügyi intézmények döntéseinek megítélése a tömegmédiumok által hatással lehet a társadalom gondolkodásmódjára és nyomást gyakorolhat a gazdasági döntéshozókra, bizonyos mértékig meghatározva a gazdasági folyamatok jövőbeni alakulását.

\section{Összefoglalás}

A gazdasági kommunikáció számos módon értelmezhető terminus, attól függően, hogy milyen jellegü elméleti megközelítésből indulunk ki. Mivel értelmezése a szerzők között nem egységes, célszerü olyan komplex gyüjtőfogalomnak tekinteni, amelynek tárgykörei felölelik a terminushoz köthető különbözö gondolattársításokat. A tárgykörök meghatározása több módon lehetséges, azonban nincs egyetlen olyan megoldás, amelynek alapján élesen elhatárolható halmazokat lehet létrehozni. Figyelembe véve a különféle elméleti megközelítéseket, alapvetően elképzelhető a közgazdasági elvű makroszintü és mikroszintü elkülönítés, amely leegyszerüsíti a tárgykörök besorolását. Célszerünek véltem három területet elhatárolni, amely a globális, a vállalati és a tömegmédia gazdasági témaköreit tartalmazza. Az így létrehozott tárgyköröket részben szervezeti szempontból elemeztem, részben Luhmann rendszerelméleti megközelítésében. A tárgykörök elnevezése: globális gazdasági kommunikáció, azaz a gazdasági élet egészét jellemző folyamatokhoz kötődő kommunikáció (Borgulya 2010 nyomán), vállalati gazdasági kommunikáció, pénzügyi gazdasági kommunikáció (Kővágó 2011 nyomán), gazdasági jellegü tömegkommunikáció (gazdasági médiatartalom) (Scholl 2008 nyomán). Az egyes tárgykörökhöz a gazdasági kommunikáció közvetítő szervezeteire hoztam példát, valamint néhány példát ismertettem a témák tekintetében, amelyek azonban nem egyetlen tárgykörhöz tartoznak, hanem különböző formában és hatással jelennek meg gazdasági kommunikáció ismertetett tárgykörein belül.

Luhmann elmélete meglehetősen absztrakt módon mutatja be a gazdasági rendszer müködését. Bizonyos tételeinek gyakorlati megvalósulása elgondolkodtató például abban a vonatkozásban, hogy nincs olyan központ, amely irányítani tudja az egész gazdasági rendszert. A gyakorlatban a teljes gazdasági rendszer a jogszabályok által meghatározott, az ezen kívüli gazdasági formákat a feketegazdaság elnevezéssel illetik, és ez nem pusztán nemzetgazdasági szinten értendő. A globális gazdaság müködését meghatározzák azok a nemzetközi szerződések, amelyeknek elfogadása az egyes nemzetállamok, pontosabban kormányok döntésének kérdése. Ebből az aspektusból tehát a politikai döntések befolyásolják a teljes gazdasági rendszer müködését. Az országok közötti kereskedelemben a protekcionizmus egyik megjelenési formája az import korlátozása (kvóták vagy vámok révén), s többnyire egyidejüleg az export ösztönzése. A protekcionista kereskedelempolitika egyfelöl az államok, integrációk védelmét szolgálja a dömping ellen, amely esetlegesen veszélyeztetheti egy nemzet vagy integráció gazdaságát (Bown 2011). Másfelől viszont a túlzott protekcionista magatartás hosszútávon fejlödés ellenes, azaz korlátozza a gazdaság bővülését, és ez elöbb vagy utóbb a GDP értékében is megmutatkozik. Ezek az intézkedések egyértelmüen állami, a rendszerszemlélet tekintetében politikai döntések, amelyek kisebb-nagyobb mértékben, de globálisan 
hatnak a gazdaság müködésére. A globális gazdasági kommunikáció színterén tehát ezeket a kérdéseket a politikai funkcionális részrendszer determinálja.

Másfelől Luhmann elgondolása a gazdasági részrendszer önszabályozó müködéséről bizonyos mértékig hasonlít Adam Smith elméletéhez, amely szerint a gazdaságot a 'láthatatlan kéz', a piaci erők irányítására kell bízni, ahol az állami beavatkozás mértéke korlátozott. A neoklasszikus közgazdászok első képviselői (Carl Menger, William Stanley Jevons, Léon Walras) Adam Smith tételei alapján szintén a piaci erőket tartották a gazdaságban kulcsfontosságúnak. Az 1929-33-as világgazdasági válság azonban egyértelmüen rámutatott, hogy a piaci erők nem képesek a gazdasági stabilitást biztosítani és a társadalomban jelentkező gazdasági problémákat megoldani (Dietmar 1989). A történelmi események igazolták, hogy az önszabályozó típusú elmélet a gyakorlatban nem, vagy csak rövidtávon biztosítja a gazdaság viszonylagos stabilitását. Ebből az következik, hogy az egyes rendszerek együttmüködése, a gazdasági rendszer bizonyos fokú irányítása szükségszerü, és fontos annak folyamatos felülvizsgálata, hogy egy adott társadalmi helyzetben ez mily módon lehetséges és célszerü.

Egyértelműen megállapítható, hogy bármely kereskedelempolitikai vagy monetáris döntés végiggyürüzik a gazdaság minden területén, meghatározva a tanulmányban vizsgált gazdasági kommunikáció tárgykörein belül érintett szereplők döntéshozatali lehetőségeit, az életszínvonalat, így a teljes gazdaság fejlődést.

Összefoglalóan a gazdasági kommunikáció olyan komplex gyüjtőfogalom, amely különféle tárgyköröket foglal magába. A tanulmányban leírtak az átláthatóság érdekében nem tartalmazzák a teljes vonatkozó irodalmat, a tárgykörök és a hozzárendelt témák nem kizárólagosak, tehát bővíthetők és kiegészíthetők más szempontokból. Úgy vélem, a gazdasági kommunikáció tárgyköreinek meghatározása hozzájárul a terminus értelmezésének tisztázásához, témaköreinek áttekintéséhez, a későbbiekben pedig a témák vizsgálata elösegítheti a gazdasági müködésnek és a gazdaság szereplöinek a jobb megismerését. Mindennek jegyében tanulmányomat azzal az idézettel zárom, hogy „Luhmann-nál a komplexitás pontosan azt jelenti, hogy nem vagyunk képesek egyszerre tekintetbe venni az összes elem összes lehetséges kapcsolatát, ezért szelekcióra kényszerülünk. Tehát a világ minden leírása szelektív, vagyis a világnak egyetlen lehetséges aspektusát mutatja, és sohasem tartalmazza az összes lehetöséget." (Brunczel 2010: 141)

\section{Irodalom}

Ablonczyné Mihályka Lívia (2006) Gazdaság és nyelv. (Lexikográfia es terminológia kézikönyvek 2.) Lexikográfia Kiadó, Pécs.

Ablonczyné Mihályka Lívia (2007) A gazdaság szereplőinek nyelvhasználata. In: Gecső Tamás - Sárdi Csilla (2007szerk.): Nyelvelmélet - nyelvhasználat. Budapest, Tinta Könyvkiadó, 6-9.

Ablonczyné Mihályka Lívia (2010) Nyelvhasználat a gazdálkodástudomány területén. In: Silye Magdolna (2010szerk.) Tudományterületek és nyelvhasználat, PORTA LINGUA. Szaknyelvoktatók és -Kutatók Országos Egyesülete, Debrecen. 249-254.

Beber, Alessandro - Brandt, Michael W. (2006) The effect of macroeconomic news on beliefs and preferences: Evidence from the options market, Journal of Monetary Economics 53., 1997-2039. https://doi.org/10.1016/j.jmoneco.2006.05.013

Beckert, Jens - Zafirovsky, Milan (2006eds.) International encyclopedia of economic sociology. Routledge, London - New York. 
Bognár Bulcsú - Karácsony András (2014) Kommunikáció és társadalom: Luhmann olvasókönyv. Gondolat Kiadó, Budapest.

Borgulya Ágnes (2010) A vállalati kommunikáció az alkalmazott nyelvészet szemszögéből. Modern Nyelvoktatás, XVI. évfolyam 2-3. szám, 2010. augusztus, 3-23.

Bown, Chad P. (2011) The Great Recession and Import Protection: The Role of Temporary Trade Barriers. The International Bank for Reconstruction and Development/The World Bank, Washington.

Bown, Chad P. (2016) Should the United States Recognize China as a Market Economy? Peterson Institute for International Economics. Number PB16-24. Washington.

Bown, Chad P. (2017) Mega-Regional Trade Agreements and the Future of the WTO, Global Policy Volume 8. Issue 1. February 2017. https://doi.org/10.1111/1758-5899.12391

Brioschi, Teodoro, Edoardo (2006) Total business communication. Profiles and problems for the new century. Vita e pensiero, Milano.

Brunczel Balázs (2010) Modernitás illúziók nélkül. Niklas Luhmann társadalom-és politikaelmélete. L'Harmattan Kiadó, Budapest.

Coda, Vittorio (1989) La comunicazione economica nella strategia aziendale. In: AA.VV. La comunicazione economica: valore aziendale o sociale. Egea, Milano.

Corvi, Elisabetta (2007) La comunicazione aziendale: obiettivi, tecniche, strumenti. Egea, Milano.

Di Stefano, Giancarlo (1990) Il sistema delle comunicazioni economico-finanziarie nella realtà aziendale moderna. Giuffrè, Milano.

Dietmar, Meyer (1989) Bevezetés a makroökonómiába. Aula Kiadó, Budapest.

Hanousek, Jan - Kočenda, Evžen - Kutan, Ali (2009) The reaction of asset prices to macroeconomic announcements in new EU markets: Evidence from intraday data. Journal of Financial Stability, 199-219. https://doi.org/10.1016/j.jfs.2008.01.003

IMF, World Bank, WTO (2017) Making Trade an Engine of Growth for All. The Case for Trade and for Policies to Facilitate Adjustment. For discussion at the meeting of G20 Sherpas. March 23-24, 2017. Frankfurt, Germany.

Kim, Suk-Joong - McKenzie, Michael D. - Faff, Robert W. (2004) Macroeconomic news announcements and the role of expectations: evidence for US bond, stock and foreign exchange markets. Journal of Multinational Financial Management, Vol. 14, No. 4, pp. 217-232. https://doi.org/10.1016/j.mulfin.2003.02.001

Kővágó György (2011) A kommunikáció elméleti és gyakorlati alapjai. Aula Kiadó, Budapest.

Luhmann, Niklas (2010) Ökológiai kommunikáció. Alkalmazott Kommunikációtudományi Intézet - Gondolat Kiadó, Budapest.

Nagy Ágnes (2009) Folyamatmenedzsment a banki szférában. Budapesti Corvinus Egyetem, Társadalomtudományi Kar, Budapest.

Nagy Ágnes (2015a) Makrogazdasági vonatkozású angol, olasz és magyar sajtócímek vizsgálata. In: Tavaszi szél konferenciakötet II. Líceum Kiadó, Eger - Doktoranduszok Országos Szövetsége, Budapest. 245-258. http://doi.org:10.17048/TSZ.2015.2

Nagy Ágnes (2015b) Caratteristiche della lingua dell'economia in base alle relative formazioni universitarie. Lingua, Corvinus Nyelvi Napok, „, Szaknyelvoktatás és multikultura- 
litás”. Tanulmánykötet. Budapesti Corvinus Egyetem, Corvinus Idegennyelvi Oktatóés Kutatóközpont, Közgáz Campus. 172-180.

Nagy Ágnes (2015c): Makrogazdasági online hírcímek a szemantikai orientáció aspektusából. In: András Hanga (2015szerk.) Kommunikációs terek. Doktoranduszok Országos Szövetsége - Partium könyvkiadó - Új Mandátum, Budapest - Nagyvárad. 120-128.

Nagy Ágnes (2016a) A számok üzenete egy gender érzékeny makrogazdaságban. In: Kommunikációs terek. Doktoranduszok Országos Szövetsége T3 Kiadó, Budapest - Sepsiszentgyörgy. 56-67.

Pearce, Douglas K. - Solakoglu, Nihat M. (2007) Macroeconomic News and Exchange Rates. Journal of International Financial Markets, Institutions and Money, Volume 17, Issue 4, 307-325. https://doi.org/10.1016/j.intfin.2005.12.004

Proietti, Domenico (2010) La lingua dell'economia e della finanza. Enciclopedia dell'Italiano: http://www.treccani.it/enciclopedia/lingua-dell-economia_(Enciclopedia-dell'Italiano) (2014. 02. 16.)

Scholl, Rosanne, M. (2008) Political and Economic Communication: Media Effects on Economic Attitudes. ProQuest.

Shaikh, Imlak - Padhi, Puja (2013) The information content of macroeconomic news. Science Direct, Procedia Economics and Finance 5 (2013) 686-695. https://doi.org/10.1016/s 2212-5671(13)00080-4

Zerfaß, Ansgar (1996) Unternehmensführung und Öffentlichkeitsarbeit. Grundlegung einer Theorie der Unternehmenskommunikation und Public Relations. Westdeutscher Verlag, Opladen.

\section{Jogszabályok}

Netjogtár 2017a: 2013. évi CCXXXVII. törvény a hitelintézetekröl és a pénzügyi vállalkozásokról és a közvetítőkröl.

Forrás: https://net.jogtar.hu/jr/gen/hjegy_doc.cgi?docid=A1300237.TV, (2017. 04. 21.)

Netjogtár 2017b: 2007. évi CXXXVIII. törvény a befektetési vállalkozásokról és az árutőzsdei szolgáltatókról, valamint az általuk végezhető tevékenységek szabályairól határozza meg. Forrás: https://net.jogtar.hu/jr/gen/hjegy_doc.cgi?docid=A0700138.TV, (2017. 04. 21.) 